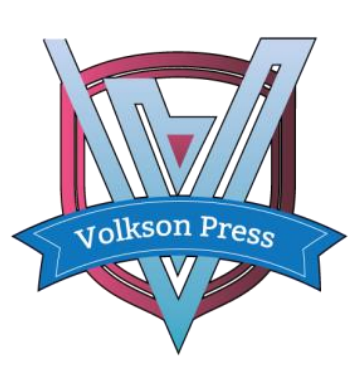

Contents List available at VOLKSON PRESS

Economics \& Management Innovations(EMI)

DOI : http://doi.org/10.26480/icemi.02.2018.21.23

ISBN: 978-1-948012-14-0

\title{
COAL MINES AS A BARRIER TO THE DEVELOPMENT OF RENEWABLE ENERGY SOURCES - BY THE EXAMPLE OF POLAND
}

\author{
Sławomir Jankiewicz \\ WSB University in Poznan, ul. Powstańców Wielkopolskich 5, 61-895 Poznań, Poland \\ *Corresponding Author email: slawomir.jankiewicz@wsb.poznan.pl
}

This is an open access article distributed under the Creative Commons Attribution License, which permits unrestricted use, distribution, and reproduction in any medium, provided the original work is properly cited.

\section{ARTICLE DETAILS}

\section{Article History:}

Received 26 June 2018 Accepted 2 July 2018

Available online 1 August 2018

\section{ABSTRACT}

The article presents an analysis of mining restructuring programs in the possession of the state to check their effectiveness and their impact on changes in the energy sector. The state policy towards the Polish hard coal mining industry in the years 1990-2018 consisted in maintaining an unprofitable industry. Public funds, which in Poland are spent on hard coal mines, are subsidies to finance their current operations, not restructuring changes. The developed recovery programs were only documents needed to obtain EU consent for the transfer of state subsidies. Maintenance of unprofitable hard coal mines is also a reason for supporting the so-called dirty electricity generation technology. The EU, succumbing to countries with coal mines, accepts funding programs for this sector. In this way, it allows further pollution of the environment and limiting the development of renewable energy, and thus the economic development of the Community.

\section{KEYWORDS}

Economic policy, environmental protection, renewable energy sources.

\section{INTRODUCTION}

Sustainable economic development is the most important goal of developed countries. [1-5]. That is why, at the level of the European Union, a lot of attention is paid to achieving this goal. In Poland, it was even written in the Constitution, that the basis for action is to achieve sustainable economic development [6].

At the Community level, the implementation of this objective is manifested, inter alia, by taking actions to limit the negative impact of raw materials sectors on the environment (including air pollution) [7-13]. The industry that has a large share in the emission of harmful compounds to the atmosphere is energy based on coal $[14,15]$. For that reason, laweconomic mechanisms are created, that are supposed to limit its negative impact on the environment $[3,10]$. On the other hand, there are created programs supporting the development of renewable energy sources (RES).

However, there are EU countries (eg. Germany or Poland) that have a large production potential in the so-called "Dirty" power plants. For example, in 2015, the gross electricity production in Germany from brown coal was $155 \mathrm{TWh}$, and hard coal $118 \mathrm{TWh}$, which made it the largest carbon dioxide emitter in Europe $[16,17]$. In Poland, about 136 TWh of electricity was produced from coal (hard coal and brown coal) in 2017. This is due to the historical past and possession of the mines that these countries do not want to liquidate and thus are not willing to quickly eliminate such plants from their assets.

Restrictive environmental protection standards mean, that the costs of units using fossil fuels significantly increase. Because of that, their competitiveness deteriorates. From an economic point of view, they should be eliminated, which would necessitate the closing of mines. States, refusing to decide, co-finance mining and power plants based on this raw material. This is done with the approval of the European Commission under the guise of restructuring or modernization of the mining and energy sector. The additional argument is the need to ensure energy security, which has been recorded in art. 194 of the Treaty on European Union [18].

The article presents a synthetic analysis of restructuring of the Polish mining owned by the state, to check the effectiveness and resources allocated to it and its impact on changes in the energy sector. The hypothesis has been verified that public funds spent in Poland on hard coal mines are subsidies that finance their current operations and not restructuring changes. Developed repair programs were only documents needed to obtain EU consent for the transfer of state subsidies.

\section{COSTS OF RESTRUCTURING PROGRAMS OF HARD COAL MINING IN POLAND}

In Poland, the restructuring of the hard coal mine was started already in 1990 , ie after the change of the economic system (transition from socialist to capitalist economy). It was mainly connected with mining funding. The largest amounts were spent in the 1990s of the XX century and before our country's accession to the EU.

It is difficult to obtain data on aid provided to this sector. The state is trying to hide the value of the transferred funds. The estimates presented in the article were based on information obtained from the report:

- Supreme Audit Office, entitled "Functioning of hard coal mining in the years 2007-2015 against the background of the government program assumptions" [19].

- $\quad$ "Hidden coal bill 2017. Support for mining and coal energy in Poland - yesterday, today and tomorrow", which was developed by U. Siedlecka, A. Śniegocki and Z. Wetmańska [20]. 
- "Polish energy sector 2050. 4 scenarios", which was commissioned by the Energy Forum in September 2017 [21].

1. and expert knowledge of the author who has been involved in the energy sector and mining for over ten years (he is, among others, a member of the Team for analysis and preparation of conditions for the implementation of high-temperature nuclear reactors, which was appointed by the Minister of Energy and the Polish Committee of the World Energy Council).

In the years 1989-2015, about PLN 66 billion (over USD 16.9 billion ) was directly spent on the mining industry from public funds (in prices from 2007). In 2016, the European Commission approved the co-financing of the mine in the years 2017-2018 with the amount of PLN 8 billion (over USD 2.42 billion ), and in 2018 for the next package PLN 5 billion (USD 1.51 billion ), which will be implemented in 2019-2023. In total, in the years 1989-2023, direct co-financing from public funds will amount to PLN 79 billion.

This should be added to the amounts transferred by the state to cover the shortage of funds for the payment of mining disablement pensions and retirements. Social insurance contributions discharged by mines are too low in relation to payments. The difference is financed from the state budget. This is done to reduce employment costs and artificially increase the profitability of the sector. In the years 2013-2016 co-financing of this type amounted to approx PLN 14 billion, and from 1990, to PLN 86.5 billion.

The EU was not officially informed about this form of support in applications for consent for public support in subsequent years, but officials of the European Commission were aware of this. The consent to this was the result of implementing two policies at the Community level. First - the official one, which results from the challenges of the modern world and concerns the fight against global warming and environmental pollution. The second (short-term), which is pragmatic and is related to the income and interests of individual states included in it - ie ensuring security, low production costs and a high rate of economic growth.

Mining support also means funds spent on the coal energy. In the years 1990-2016, the Polish state jointly spent about PLN 230 billion (in prices from 2016) on co-financing of the mine and coal energy. In the last decade, the average unit support for coal-based energy reached PLN 45 / MWh, which corresponds to about $1 / 4$ of the price on the wholesale market.

In spite of financing, the mining sector has a problem with profitability all the time. This is due to the fact that was afraid the reaction of miners who were a strong social force in Poland. No restructuring was carried out because mine employees did not agree to reduce employment and reduce wage growth. In addition, the government of Donald Tusk (in power in 2007-2015) did nothing to heal the sector, because it was more important to preserve the political coalition. As part of the party divisions, the mines were managed (appointed managers) by the coalition in the government the PSL party. Undertaking corrective actions required appropriate qualifications, which people nominated by PSL did not have. This sector was treated as a source of funding for party activists. This was admitted officially by the Deputy Prime Minister of the government, E. Bieńkowska . The political management led to net losses in mining, which in 2013-2015 amounted to PLN 6.9 billion.

The new government (PiS), which took power in 2015, did not change policy towards hard coal mines. The only decision was made that the power industry would engage capital in the mines and thus will additionally finance the losses of this sector. It was determined that the state will directly refinance part of these costs under the guise of ensuring energy security, and the remaining expenses will translate into society in the form of higher energy bills.

According to estimates, the implementation of the adopted policy on coal and mining is another 155 billion PLN of support by 2030, and the costs related to the mechanism of remuneration for the reserve of power (It was created with the EU's consent to support coal mining.) will amount to around 27 by 2027 PLN billion and over PLN 8 billion in the next three years. To the costs of coal support policy should be add external effects (eg emission of harmful gases to the environment or deterioration of public health), which are not included in any estimates.
For comparison, has to be written about support in Poland for renewable energy sources (RES). In the years 1990-2016, such sources received cofinancing in the amount of PLN 17 billion, including PLN 9 billion in the years 2013-2016The section headings are in boldface capital and lowercase letters. Second level headings are typed as part of the succeeding paragraph (like the subsection heading of this paragraph).

\section{EVALUATION OF MINING RESTRUCTURING PROGRAMS IN POLAND}

In Poland, mines and coal energy received, as previously stated, significant co-financing from public funds. It will be maintained in the following years (the government assumes that until around 2050). The official reason was to restructure the sector in order to restore its sustainable profitability.

After Poland's accession to the EU, the program implemented in 20072015 , which was to restore the sustainable profitability of hard coal mining, was important for the industry. Counting from 1990, it was the seventh government program for this sector. It was accepted in July 2007 by the PiS government, while it was realized by PO and PSL governments. The analysis shows that the program was developed unreliable. First of all, it was based on overly optimistic assumptions (eg inflated demand for coal, its export volume and sales prices). The forecasts were deliberately overstated so that it would be easier to get the Community's agreement to finance the restructuring by the state.

Secondly, the plan was developed very vaguely. It did not take into account the actual situation of individual enterprises. Only average values for the entire sector were used. Thirdly, the Ministry of Economy (which oversees the mines) not only did not force individual companies to develop professional strategic plans, but also failed to monitor whether corrective measures were implemented. Therefore, the mining sector did not change its behavior and acted mainly on the basis of year plans, and so it focused on current issues and ignored strategic changes.

Formally, the program presented a quick restoration of the profitability of the mine and maintaining high profitability by it. In practice, it was a document that presented the general directions of restructuring activities at very optimistic shaping of the external environment. His task was not to bring about changes (it was not to be the basis for creating plans in individual enterprises) but obtaining the EU's consent for another financing of an unprofitable industry by the state. Creating the program did not assume that it will be implemented.

Therefore, it is not surprising that after the end of subsidy by the government, mining faced financial problems. The opportunity offered by public support, good economic situation of hard coal and relatively high prices of this raw material were not used to reduce employment and fixed costs, and to increase productivity. Some economic indicators have even been deteriorated. For example, after the implementation of the program from 2007-2015, the efficiency was lower than in 2006 and significantly differed from that in private mines. The average efficiency in the years 2013-2016 was about 600 tons per year for one miner (for companies whose shareholder was the state), while in the privatized Silesia mine approx. 1000 tons, and Bogdanka 1.630 t. On the other hand, wages and other liabilities increased significantly. The government did not have the idea to restructure the industry. Government did not want to privatize enterprises, to private capital would take care of it. The result was large losses of individual companies, which led to their loss of liquidity and thereby blocking the possibility of obtaining external financing.

In 2015 , the mine's standing was so bad that the estimated costs of rescuing mining industry exceeded the capacity of the state budget. It was decided to use for this purpose also funds from the EU and energy companies. The first two sources of financing (state and communal) required the consent of the European Commission, which Poland received on the basis of another "fictitious" restructuring plan . The third source required the forcing of energy enterprises to capital involvement in mining. It was not difficult because their dominant owner was the State Treasury. In 2017, the power industry subsidized the mines and, as a coowner, became responsible for the processes taking place in mining.

However, the costs of rescue were, higher than forecasted. Therefore, it was decided to additionally help the energy industry by creating so-called power market. It is based on the fact that the state provides co-financing for power plants that will be classified as important for the country's energy security. The amount obtained from the state is the higher the higher the costs of their operation, which will ensure adequate 
profitability of power plants (in the extreme case even if they will not generate electricity). Such status was obtained by coal-fired power plants, both present and newly built (earlier they would not have been created due to negative NPV). The European Commission also agreed to these activities, and thus indirectly agreed to support coal mines and "dirty" energy.

Officially, the government declared that these measures would allow bringing the mine to profitability and achieving a synergy effect in the energy and mining industry, which will translate into better results for coal-fired power plants. In practice, it can be different. Both, new and existing coal-fired power plants, can have significant problems with profitability. The high costs of coal mining and the need to meet stringent emission requirements (including maximum $\mathrm{CO} 2$ emissions lower than 550 g per KWh) will cause that the current generated on the basis of coal will be expensive and will not find buyers on the market. Especially, that no corrective measures were taken at hard coal mines, and the acquisition of significant funds, affected employees' claim attitudes (eg in 2018, they gained a $7 \%$ pay rise despite poor financial results and high indebtedness, and receiving 14 salaries a year instead of standard 12). Meeting the competition requires, on the other hand, productivity increase per one miner to approx. 2,000 tons per year and considerable capital expenditure [21]. Problems with mining cause that the state is trying to limit the development of renewable energy, because it may threaten the financing of unprofitable mines.

The risk associated with the deterioration of the situation in the energy sector due to the maintenance of the coal economy is noticed by many economists, including EU experts (eg Prof. P. Kapros). It will result from cheap renewable energy available on the market, which due to technological development (which will increase efficiency and reduce investment costs) will develop significantly [22].

\section{CONCLUSIONS}

So called dirty electricity generation technologies are being supported in the EU. On the one hand, the lobby of large enterprises and social groups has an impact on it. On the other hand, the desire to become independent from imported raw materials, and thus increase the country's security. The mechanism of co-financing for hard coal mines and dirty energy in Poland presented at work also applies to other EU countries (eg Germany). It is, therefore, necessary to change the Community policy in this area. Otherwise, we not only degrade the environment, but also limit the innovation (and thus competitiveness) of the Community by wasting resources. A much better solution would be to use them to build a knowledge-based economy. This would not only help improve the GDP growth rate, but also the quality of life of the EU society.

This also applies to Poland, which (as noted by P. Kapros) has a large potential for developing biomass energy. Using it would allow for energy independence without significantly increasing gas imports and further development of coal-based energy. Unfortunately, the EU, submitting to countries with coal mines, accepts funding programs for this sector. In this way, it allows further pollution of the environment and limiting the development of renewable energy, and thus the economic development of the Community.

\section{REFERENCES}

[1] WCED. 1987. Report of the WCED „Our Common Future”, Genewa.

[2] United Nations. 2012. Report of the United Nations Conference on Sustainable Development, Rio de Janeiro.
[3] Dyrektywa Parlamentu Europejskiego i Rady 2009/28/WE z dnia 23 kwietnia 2009 r. w sprawie promowania stosowania energii ze źródeł odnawialnych zmieniająca i w następstwie uchylająca dyrektywy 2001/77/WE oraz 2003/30/WE, Dz.U. UE L 09.140.16.

[4] Europejska, K. 2011. Nasze ubezpieczenie na życie i nasz kapitał naturalny - unijna strategia ochrony różnorodności biologicznej na okres do 2020 r., Bruksela.

[5] Jankiewicz, S. 2017. Uwarunkowania polityki gospodarczej. WN PWN, Warszawa, pp. 26-32.

[6] Konstytucja Rzeczypospolitej Polskiej z dnia 2 kwietnia 1997 r., Dz. U. nr 78, poz. 483.

[7] Europejska, K. 2001. Zrównoważona Europa dla lepszego świata: Strategia zrównoważonego rozwoju UE, Bruksela.

[8] Europejska, K. 2007. Pakiet klimatyczno-energetyczny UE. Bruksela.

[9] Europejska, K. 2010. Europa 2020. Strategia na rzecz inteligentnego i zrównoważonego rozwoju sprzyjającego włączeniu Społecznemu, Bruksela.

[10] Europejska, K. 2011. Plan działania prowadzący do przejścia na konkurencyjną gospodarkę niskoemisyjną do 2050 r., Bruksela.

[11] Europejska, K. 2011. Mapa drogowa do niskoemisyjnej gospodarki do 2050 r., Bruksela.

[12] Europejska, K. 2012. Inwestycje w przyszłość: więcej miejsc pracy dzięki bardziej zielonemu budżetowi. Bruksela.

[13] Europejska, K. 2011. Nasze ubezpieczenie na życie i nasz kapitał naturalny - unijna strategia ochrony różnorodności biologicznej na okres do 2020 r., Bruksela.

[14] European Commission. 2012. EnergyRoadmap 2050, Publications Office of the European Union, Luxembourg.

[15] European Commission. 2015. Commission unveils key energy infrastructure projects to integrate Europe's energy markets and diversify sources, Luxembourg.

[16] BDEW. 2016. Erneuerbare Energien und das EEG: Zahlen, Fakten, Grafiken.

[17] Eurostat: Total greenhouse gas emissions by countries, http://ec.europa.eu/eurostat/statistics explained/index.php/Greenhouse_gas_emission_statistics.

[18] Wersja skonsolidowana Traktatu o Unii Europejskiej i Traktatu o funkcjonowaniu Unii Europejskiej, Dz. U. UE C 83 z 30 marca 2010 roku.

[19] Kontroli, N.I. 2017. Funkcjonowanie górnictwa węgla kamiennego w latach 2007-2015 na tle założeń programu rządowego, Warszawa.

[20] Siedlecka, U., Śniegocki, A., Wetmańska, Z. 2017. Ukryty rachunek za węgiel 2017. Wsparcie górnictwa i energetyki węglowej w Polsce wczoraj, dziś i jutro, WiseEuropa, Warszawa.

[21] Polski sektor energetyczny 2050. 2017. 4 scenariusze, Forum Energii, Warszawa.

[22] Jankiewicz, S. 2006. Podstawy polityki gospodarczej, AE w Poznaniu, Poznań. 